\title{
International Approaches To Renewable Energy Education - A Faculty Professional Development Case Study With Recommended Practices For STEM Educators
}

\author{
Kenneth A. Walz, Madison Area Technical College, USA \\ Mary Slowinski, University of Washington, USA \\ Kathleen Alfano, College of the Canyons, USA
}

\begin{abstract}
Calls for increased international competency in U.S. college graduates and the global nature of the renewable energy industry require an exploration of how to incorporate a global perspective in STEM curricula, and how to best develop faculty providing them with global knowledge and skills necessary to update and improve existing teaching practices. To expand awareness of the global renewable energy sector, a cohort of renewable energy educators from across the United States participated in two international learning exchanges to Australia/New Zealand and Germany/Denmark. The exchanges provided opportunities for the participants to meet with technical educators, visit teaching labs, review industry partnerships, talk with policy makers and government representatives, and to share knowledge and best teaching practices. Three years after the initial international exchange, participant data was collected to measure the extended impact of the experience and the perceived value of various learning activities. The results show that the exchanges expanded participant's knowledge of renewable energy technologies and issues both in the U.S. and abroad, and also influenced teaching curriculum and instruction, and academic community engagement. This study serves as a model program for providing STEM faculty with rich international experience. The findings in this manuscript highlight the key components to building a successful international professional development program, and illustrate the type of impacts that can result from these activities. The lessons learned are meaningful to other institutions or organizations planning similar international activities in a variety of disciplines.
\end{abstract}

Keywords: International Programs; Faculty Professional Development; Renewable Energy; Curriculum And Instruction

\section{INTRODUCTION}

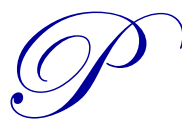

reparing STEM students for employment in the renewable energy sector is a multifaceted challenge for educators. Rapid technological advances, emerging research results, changing regulatory guidelines, shifting economic policies, ideological debates, and even global environmental and climate agreements actively shape and influence the demands and expectations for this sector's workforce, all of which impact the development and implementation of renewable energy education programs. The need for industry involvement and workplace-based learning also presents challenges for workforce educators of any discipline.

In addition to these factors, companies involved in the renewable energy sector are increasingly multinational in scope; international corporations such as Abengoa, BP, First Solar, General Electric, Hitachi, Hyundai, Iberdola, Mitsubishi, Nordex, Novozymes, NRG, Panasonic, Samsung, Sharp, Siemens, Trina, Vestas, and Yingli are just some of the influential global leaders in this industry. Professionals entering careers in the renewable energy field 
need to be aware of, and prepared for, participation in the global economy. Furthermore, to prepare students for this multinational industry, instructors teaching renewable energy need to develop a fundamental global literacy and awareness of international energy trends for themselves.

Of course, the growth of global industry entities is not limited to renewable energy. Numerous calls for action in the education sector, including the National Academies' Educating the Engineer of 2020, have recommended expansion of opportunities for international study related to science, technology, and engineering (NAE, 2005). Similarly, the Blue Ribbon Lincoln Commission (2005) in its' publication on Global Competence and National Needs stated : "It is no secret to anyone that the United States is buffeted by international forces...Modern technologies, communications, and transportation systems have remade manufacturing and distribution on a global scale...Increasingly, business leaders recognize that they must be able to draw on people with global skills if their corporations are to succeed in a world in which one American job in six is tied to international trade." These conclusions were reinforced and quantified by a recent survey that found almost $40 \%$ of companies surveyed missed international business opportunities because of a lack of internationally competent personnel (Daniel et al, 2013).

Research has shown that students who study abroad are twice as likely to find employment within a year of graduation, and earn starting salaries $25 \%$ higher than their peers (Preston, 2012). However a variety of barriers, including financial constraints and family obligations, limit the number of students who can take advantage of such opportunities. Only 304,467 U.S. students studied abroad for credit during the 2013-2014 academic year, representing a mere 1.5 percent of all U.S. students (NAFSA, 2015). Unfortunately, even at colleges with active study abroad programs, student participants tend to be foreign language and liberal arts students; study abroad participation by students in skilled trades, science, engineering, and other technical programs is quite rare. This further emphasizes the need to internationalize the curriculum in existing domestic STEM programs, so that students who lack first-hand international experience are nevertheless provided with opportunities to develop global literacy skills and to prepare for the global workforce.

Against this backdrop, the challenges facing STEM educators in emerging fields such as renewable energy include not only identifying critical knowledge and skills presented by new technology, but also determining how to incorporate an international perspective in technical curricula. Likewise, from a professional development standpoint, the question becomes how to prepare faculty and empower them with international expertise so that they may teach the renewable energy professionals of the future.

\section{PURPOSE}

In response to these needs, the California Regional Consortium for Engineering Advances in Technological Education (CREATE) proposed the development of international learning exchanges to provide a cohort of renewable energy faculty with relevant international exposure in their discipline. As a result, the National Science Foundation's Advanced Technological Education program funded two CREATE learning exchanges. Participants were charged with learning how their international peers had met similar challenges teaching renewable energy, with expanding their knowledge of the global renewable energy sector, and with sharing the results of their study. Fourteen nationally recognized educators from across the U.S. were selected to participate; expertise in U.S. energy technician education across renewable energy disciplines was ensured by the inclusion of participants with expertise in biofuels, building efficiency, education policy, energy policy, geothermal power, solar power, and wind power. The group met with technical educators, visited renewable energy teaching labs and installations, reviewed industry partnerships, and talked with policy makers and government representatives in Australia/New Zealand (2013) and Germany/Denmark (2014). The goals of both learning exchanges were to provide participants with access to:

- best practices in teaching methods, course content, industry certifications, articulation and career pathways for renewable energy professionals in the U.S. and abroad

- first-hand experience and fundamental baseline knowledge of international renewable energy practices and policies that would enable the globalization of courses, curricula and programs taught in the U.S.

- in-depth exposure to and discussion of national energy policy and its impact on renewable energy education in the host countries and in the U.S. 
Formative assessments during these projects indicated that these exchanges increased participant knowledge in terms of renewable energy advances, technologies, and regulatory/policy issues both in the U.S. and abroad, and influenced participants' teaching, administration and educational outreach activities. This paper presents a summation of the teams key findings and recommendations for renewable energy education, while also documenting the lasting impacts on participants' teaching practice, curriculum development, professional knowledge and academic community engagement. Educator rankings of the most valuable aspects of the international experiences highlight key strategies for international faculty professional development. To provide guidance for others seeking to create similar international faculty development programs, a summary of recommended practices is also included.

\section{METHODS}

\section{Participant Selection: Assembling a Community of Practice}

As noted in the introduction, the participants in this project were all professional educators involved in renewable energy technician education. To ensure the creation of a robust community of practice, invitations for participation were distributed to create a mix of discipline areas within the renewable energy and energy efficiency sectors; participants were then chosen through a competitive nomination, application, and selection process that required a written applications and curriculum vitae submitted by the applicant, along with two letters of recommendation provided by college administrators. Of the fourteen participants over two projects, eleven were educators at the twoyear college level, two were full-time administrators of renewable energy programs that operate within the two-year college system and one taught STEM curricula and administers an advanced engineering program at the high school level. The final distribution of expertise in the group provided representation for solar energy (3), building efficiency (2), wind power (3), bioenergy/biomass (2) and geothermal energy (2). Two participants provided expertise on educational policy and the administration of renewable energy education programs, and several had experience with regulatory and energy policy issues as well. Some of the participants also had experience as instructors/mentors in teacher preparation programs, or as adjunct faculty at the graduate level. All participants were conversant and well informed on the curricula and methodologies currently used to educate renewable energy technicians in the United States.

\section{Australian Learning Exchange 2013}

The itinerary for the Australian learning exchange (see Table 1) included meetings with a variety of stakeholders who contributed to the development of Australian renewable energy industries, education, and policy - including Australia's experience with the world's first carbon tax, which was introduced in July 2012, and then subsequently repealed in July 2014 (ABC, 2014). The trip emphasized interaction with educators at the Australian Technical and Further Education (TAFE) institutions, which are somewhat similar to two-year technical colleges in the U.S. The group visited seven TAFE institutions located in the states of New South Wales, Queensland, Victoria and the Canberra Capital Territory. Given that the Australian continent is roughly as large as the United States, this geographical diversity was important. The locations visited ranged from the tropical environment of Cairns $\left(16^{\circ}\right.$ South), to the high latitudes of Melbourne ( $38^{\circ}$ South), and the adoption of various renewable energy technologies differed somewhat based on local climate and resources. The group also met with the Australian American Steering Committee on Science and Technology, the Construction Industry Skills Council, and the Clean Energy Council. Industry tours included an advanced biofuel R\&D installation, and the Commonwealth Scientific and Industrial Research Organization Energy Centre (similar to the U.S. National Renewable Energy Laboratory). 
Table 1. Itinerary for the Australia International Renewable Energy Learning Exchange, 2013

\begin{tabular}{l|l}
\hline Date & \multicolumn{1}{c}{ Institution Visited } \\
\hline $3 / 12$ & TAFE Directors Meeting, Sydney \\
\hline $3 / 12$ & Northern Sydney Institute of TAFE \\
\hline $3 / 13$ & Western Sydney Institute of TAFE, Nirimba Campus \\
\hline $3 / 13$ & Western Sydney Institute of TAFE, Richmond Campus \\
\hline $3 / 13$ & Commonwealth Scientific and Industrial Research Organization Energy Centre \\
\hline $3 / 14$ & Canberra Institute of Technology \\
\hline $3 / 16$ & Tropical North Queensland Institute of TAFE \\
\hline $3 / 18$ & Chisholm Institute of TAFE \\
\hline $3 / 18$ & Holmesglen Institute of TAFE \\
\hline $3 / 19$ & Clean Energy Council \\
\hline $3 / 19$ & Direct Energy \\
\hline $3 / 20$ & Northern Melbourne Institute of TAFE \\
\hline $3 / 21$ & Luigi Rosselini Architect Firm \\
\hline $3 / 22$ & Licella Biofuel Plant \\
\hline & TAFE Directors Meeting, Sydney \\
\hline
\end{tabular}

At the TAFE institutions, participants met with renewable energy faculty, toured facilities, and learned about the academic programs available to students. Each of the individual TAFE schools had pursued renewable energy technology education according to the resources provided by their geographic region and the needs of their local industry. One of the common findings among all of the TAFEs was the major investment that had been made in educational training facilities. Every campus had seen major construction or remodeling projects executed over the last 5-10 years to provide state of the art renewable energy training facilities. Many of these included new low carbon footprint or net-zero energy buildings that had been erected on campus. Another common observation was the focus on water conservation. As a result of Australia's decade long drought, various advanced water technologies had been employed that included water conservation, large scale rain water harvesting, grey water recycling, and on-site waste water treatment facilities. The various water conservation efforts were a feature of every campus tour included in the itinerary.

Participants also met with industry experts to learn about unique renewable energy technologies being developed in Australia. This included an afternoon with representatives of the electrical utility Ergon. Ergon serves numerous islands off the coast of Queensland, and has been exploring options to provide power to these isolated areas using distributed renewable energy resources, including wind, solar and biogas digestion. The group also visited the CSIRO national laboratory, where they toured several experimental renewable energy projects. CSRIO works with Australian industry to advance new technologies, such as dye-sensitized solar cells that seek to replace traditional silicon technology with an electrochemical pigment similar to that found in the leaves of plants. The group also visited Licella Biofuels, which is commercializing biofuel technology originally developed at the University of Sydney. Unlike most North American cellulosic biofuel plants that employ biological or thermochemical processes (e.g. fermentation or gasification), Licella uses a proprietary supercritical water process to convert biomass feedstock into a product that is similar in composition to crude oil. 
Figure 1. CREATE Participants view the Licella biofuel reactor in Somersby, Australia.

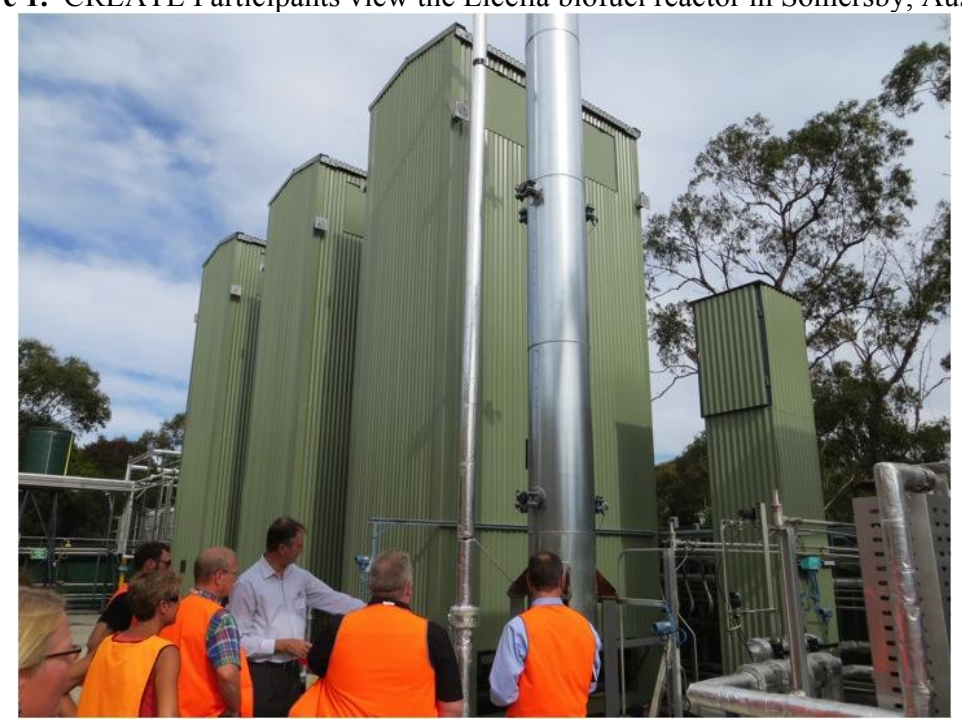

\section{German Learning Exchange - 2014}

The German learning exchange was also designed to provide participants with exposure to a variety of perspectives on the German renewable energy sector and opportunities to witness first-hand the impact of Germany's Energy Transition, the Energiewende (Agora, 2015). The group first met in Washington D.C. at the Heinrich Boell Foundation for a series of lectures designed to provide information on the German school system, the German political structure and the Energiewende itself. Once abroad, introductions to educators and educational programs were again emphasized, this time through visits to Berufschule, Fachoberschule, and Fachhochschule institutions that are roughly similar to two-year college level technical programs in the U.S. (Slowinski and Alfano 2015). The group visited a total of 16 sites including three technical schools/universities, three for-profit training schools, three industry sites (geothermal plant, biogas plant, wind turbine manufacturer), two energy self-sufficient communities (Feldheim, Folkecenter), and five government/policy advocacy organizations. This diversity of sites was intended to assist the participants in better understanding the impact of the Energiewende on technician education from many points of view. An overview of the German itinerary is shown in table 2.

Table 2. Itinerary for the Germany International Renewable Energy Learning Exchange, 2014

\begin{tabular}{c|l}
\hline Date & \multicolumn{1}{|c}{ Institution Visited } \\
\hline $5 / 30$ & Boell Foundation \\
\hline $5 / 31$ & Hessian State Office for Technical Training (HST) \\
\hline $6 / 2$ & Berufschule Gross-Gerau (BSGG) \\
\hline $6 / 3$ & Berufschule Butzbach \\
\hline $6 / 3$ & Wallerstädten Biogas Plant \\
\hline $6 / 4$ & Technische Universitat Darmstadt \\
\hline $6 / 5$ & Insheim Geothermal Plant \\
\hline $6 / 5$ & Renewables Academy (RENAC) \\
\hline $6 / 6$ & Life E.V. Education and Environment Non-Profit \\
\hline $6 / 6$ & Agora Energiewende \\
\hline $6 / 6$ & Federal Ministry for Economic Affairs \& Energy (BMWI) \\
\hline $6 / 7$ & German Solar Energy Society (DGS) \\
\hline $6 / 8$ & Feldheim Energy Independent Community \\
\hline $6 / 9$ & Bundestag/Reichstag \\
\hline $6 / 9$ & BZEE Industry Training Center for Renewable Energy \\
\hline $6 / 11$ & Senvion Wind Energy (formerly RE Power) \\
\hline & FolkeCentre Energy Independent Community \\
\hline
\end{tabular}


Two key themes emerged from meeting with German policy makers. First, that the Energiewende is not an issue advanced by a specific political party; and second, that the Energiewende is not exclusively about renewable energy. Legislative support for the German Energiewende passed in late 2010 with $85 \%$ of parliament members voting in favor, and $93 \%$ of German citizens supported it as of 2015. The Energiewende includes greenhouse gas (GHG) reductions of $80-95 \%$ by 2050 , and to meet this goal, most if not all of Germany's existing coal-fired electrical generation will need to be retired. The Energiewende also incorporates the goal of phasing out all of Germany's remaining nuclear reactors by the year 2022. Given these considerations, renewable energy will be tasked with an increasingly prominent role in the German electric portfolio, and it is expected to grow to $60 \%$ by 2050 . However German policy experts were quick to emphasize that the Energiewende has three pillars - Energy Conservation, Renewable Energy, and Grid Modernization - and all three are crucial to the success of the Energiewende.

The three pillars of the Energiewende were on display at each of the educational institutions visited. Participants could not help but notice that German buildings were highly energy efficient. Features such as day lighting, natural ventilation, and occupancy sensors were ubiquitous in the German buildings. Many of the schools featured buildings designed and constructed using the German Passivhaus standards for energy efficiency, which results in ultra-low energy buildings that require little energy for space heating or cooling. Other technologies such as building integrated photovoltaics, and solar water heating were also common. Furthermore, the Berufschule programs had adopted a holistic approach to renewable energy education that incorporated elements of building science, construction, and skilled trades to evaluate the entire energy footprint of a given home, school, or workplace. The third pillar of the Energiewende was the focus of work done at the University of Darmstadt to train engineers and operators for the modern electrical grid. Participants observed students demonstrating a live microgrid laboratory and a computer simulator to model a grid that incorporated traditional coal and nuclear generating plants, along with variable sources such as wind turbines and solar panels, as well as energy storage technology in the form of modular $5 \mathrm{MWh}$ batteries, such as those being developed by the German company Younicos.

In addition to the educational meetings, the group also visited sites to learn about novel renewable energy technologies being developed in Germany. The group toured the Wallenstadt biogas digester, which is unique in several aspects. The digester is fueled with a mixture of animal manure, dedicated energy crops and agricultural waste, utilizes a recycling of digester solids treated with fungi to extract additional energy from the biological material, and has an organic Rankine cycle heat recovery electrical generator located downstream of the traditional internal combustion engine generating unit. Participants learned about advanced geothermal energy at the Pfalzwerk geothermal plant in Insheim, where water is injected into a 12,000 foot deep well and returns to the surface at $165^{\circ} \mathrm{C}$. By comparison, geothermal plants in the U.S. tend to be conventional sites making use of high temperature steam that is either available naturally at the surface or is produced with much shallower wells $(<1000$ feet deep). As discussed with the German engineers the difference is significant, since the time required for development, the complexity of the operation, and the cost associated with tapping the Insheim resource is considerably greater than that of existing U.S. geothermal plants. The itinerary also featured visits to two energy independent communities in Hurup Thy, Denmark and Feldheim, Germany. The latter included a tour of one of Germany's newest wind farms, which was still under construction at the time. The Feldheim wind farm featured Enercon's 3MW direct drive low speed synchronous annular generator turbine. The turbine differs from most machines installed in North America, employing a gearless direct drive mechanism and a tower that is assembled on site from pre-cast concrete sections. 
Figure 2. CREATE Participants enter the base of an Enercon turbine at the Feldheim wind farm.

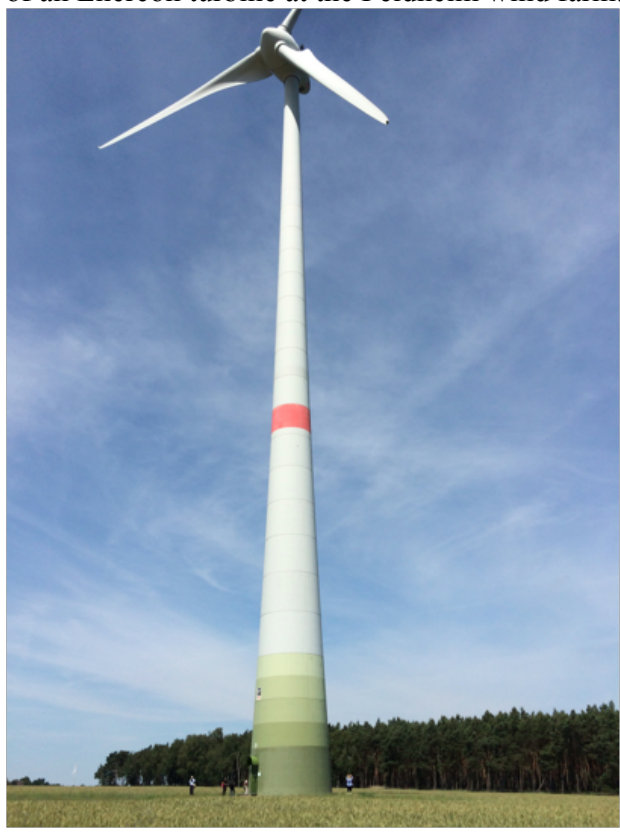

\section{Knowledge-Building Activities}

Learning activities and deliverables were developed in order to deepen and broaden the knowledge gained by participants, while also capturing and preserving their findings for the purposes of dissemination and grant reporting. Most of these activities and deliverables were facilitated and supported through the use of an online "course" site hosted on Instructure's Canvas learning management system (see Figure 3). Reports, discussions and other artifacts were collected on the site as well. Conference calls and webinars were also used to connect the group.

Figure 3. Screen Capture of the Canvas Learning Management System Dashboard and Menu of Knowledge Building Activities.

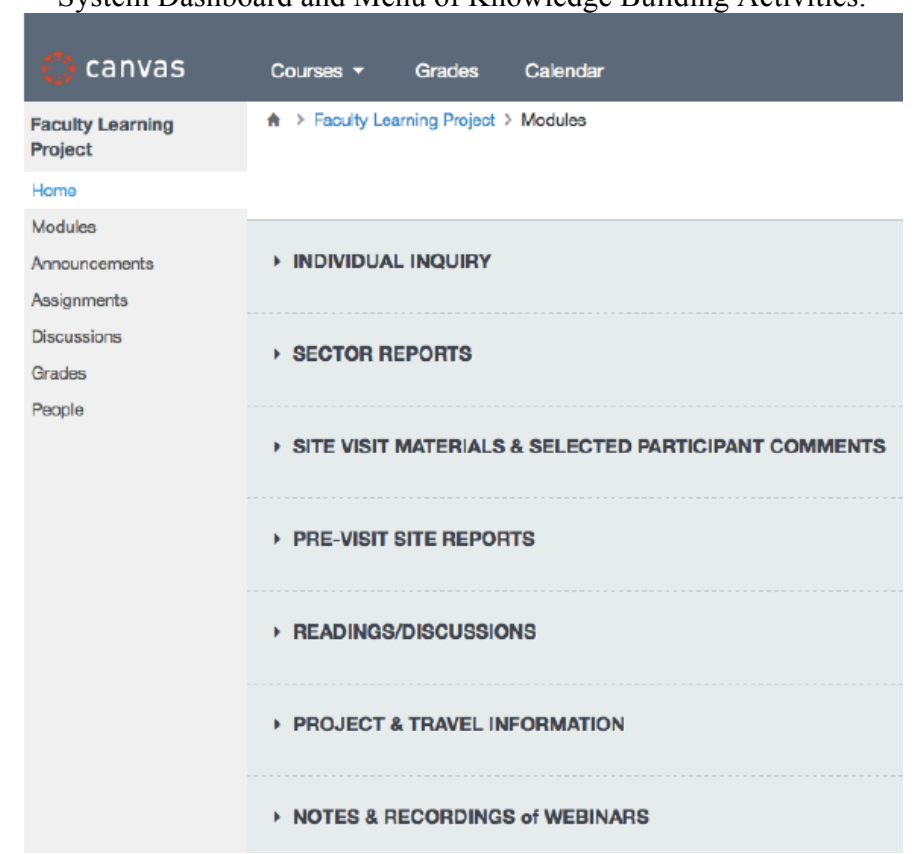


Reading/Discussion: Prior to travel, participants were asked to review selected readings as posted on the Canvas site each week; topics included the Australian and German school systems, government structures, regulatory and policy specifics, and technical information regarding various renewable energy technologies. These weekly readings were followed by mandatory, guided online discussions.

Pre-Visit Site Reports: Participants were assigned 1-2 sites that the group would be visiting for which they created and shared a "pre site visit" report form. This required that they investigate - and in some cases contact - the schools, agencies or industry sites; these reports were posted to the Canvas site and presented by the authors during a series of webinars. During travel, the pre-visit site reports were also read aloud by the authors while the group was en route to each site; this allowed participants to ask questions and share knowledge and also anchored the experience prior to arrival.

Pre- and Post-Travel Surveys: Pre- and post-travel surveys were completed by all of the educators participating in the learning exchange and were used to measure the knowledge gained by the teachers.

Individual Inquiry: Participants, with the assistance of the learning coordinator, selected an area of investigation that was key to their practice as an educator or renewable energy expert. These questions guided the participants' informal research while traveling and resulted in short reports after travel.

Site visit reports: Participants completed reports for each site visited. These forms consisted of five question prompts and resulted in formative, reflective reports that captured their experiences at each visit and also acted as informal journals that they could use in the future to identify trends, concepts and/or innovations that they found notable. The reports also served as a record for their continued investigation into their individual inquiry question(s).

Sector Reports: Upon return, participants were paired up on teams based on their specific area of renewable energy expertise to complete sector reports which compared and contrasted the German and U.S. energy industry, educational pathways, industry involvement in education and specific observations about curriculum and/or teaching methodology.

The initial participant reports were completed while abroad and analyzed upon return to assess participant learning and to determine their perspectives on the renewable energy educational practices of Australia and Germany in comparison with that of the United States. The findings from these activities were further developed and refined through two conference paper submissions and a series of panel discussions that participants engaged in to disseminate their experience (Slowinski et al., 2015 and 2016). The results reported below summarize the key points from the knowledge building activities along with themes that emerged from panel discussions held at the National Science Foundation Advanced Technological Education (2014 and 2015), STEMtech (2015), High Impact Technology Exchange (2014 and 2015), American Association for Advancement of Science (2016), and American Society for Engineering Education (2015 and 2016) conferences.

\section{Measuring Impacts on Educational Practice}

Long-term impacts resulting from the project were measured in January 2016, a full three years after the first learning exchange to Australia and a year and a half after the completion of the second international experience in Germany. A web-based survey was created to measure the impact of the international exchange projects across several areas - including changes in classroom practices and teaching, curriculum development, professional knowledge and academic community engagement. The survey also collected participant assessments of personal growth and global awareness. To identify the most important aspects of the structure and function of the international programs, the survey measured participants perceived value of various learning activities included in the experience.

Survey responses were automatically aggregated prior to analysis to identify trends and common responses. For questions employing Likert-like scales, the percentage of respondents selecting a given response was reported, and weighted averages were also calculated to rank importance and facilitate interpretation of the results. Textual data 
were analyzed inductively using a grounded theory approach. Open-ended text responses were analyzed independently by each of the authors, and their conclusions were then compared to one another to discern patterns and themes that emerged. A sample of the question format employed in the survey is shown in Figure 4.

Figure 4. Internet browser screenshot illustrating the survey question format.

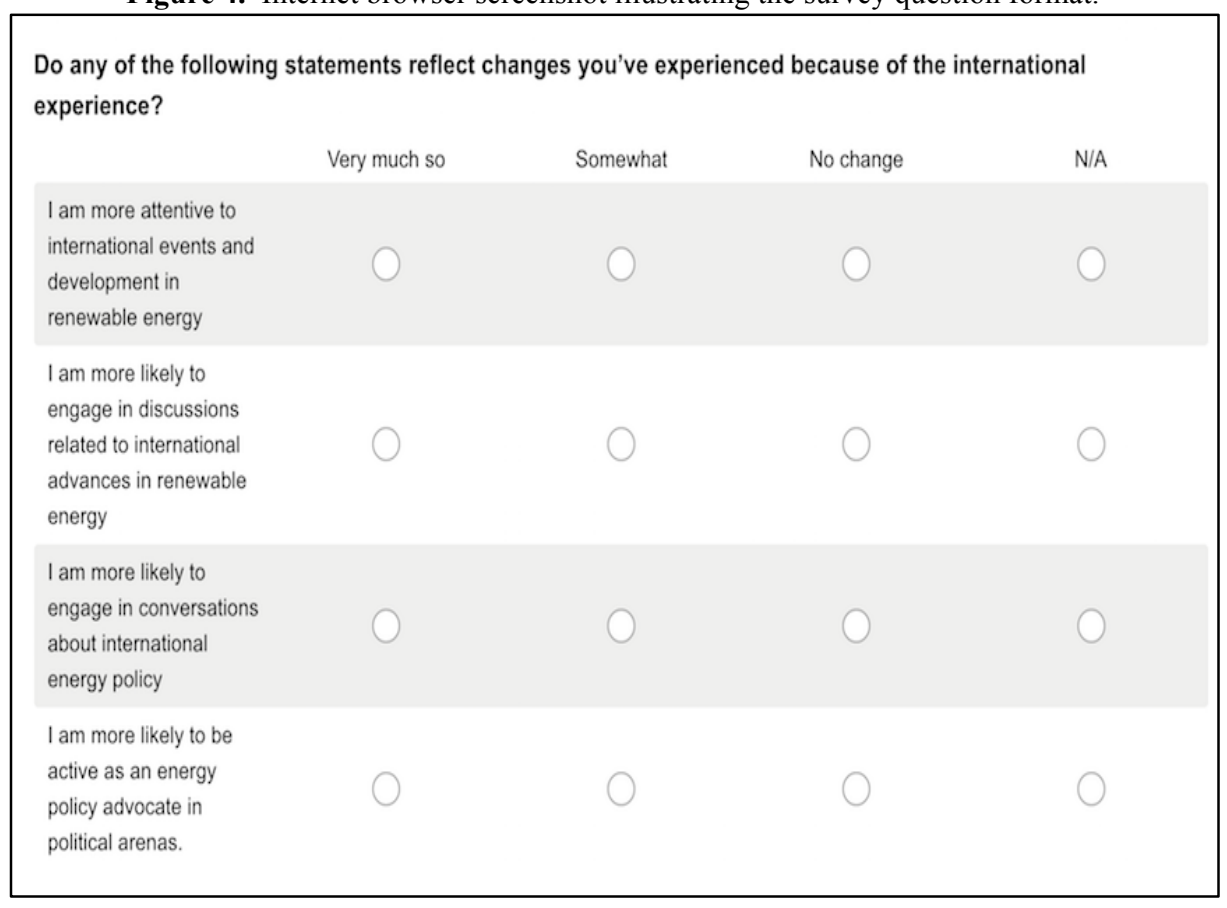

The survey was administered using Survey Monkey, an online service widely used for education and social science research, and was available for ten days (January 13 to January 22, 2016.) Initial email invitations were sent to all 14 participants across the two projects with email reminders issued to non-responders on days 5,7 and 9 . Response rates were steady over the ten-day open period and culminated in a final response rate of $86 \%$ with all surveys completed in full. Of the 12 respondents, 9 were faculty members holding instructional positions, and 3 held administrative positions (project director, dean, etc.). All but one of the respondents worked at two-year colleges, with 10 of the institutions offering Associate Degrees in renewable energy, and 10 offering technical Diplomas or Certificates.

\section{RESULTS}

Educational finding \#1: Establishment of a national vision for energy policy is a key ingredient to establishing a consistent approach to renewable energy education. The contrast between the German and Australian experiences in renewable energy education was dramatic, and provided a context for examination of our own policies in the United States. What makes the difference, wrote one participant, is that "Germany's Energiewende provides a long-range outlook on energy planning, whereas in Australia and the U.S. plans are typically based on short-term market forces." This was echoed by another participant who stated, "The most striking thing is that Germany actually has national energy goals with strategies and policies designed to achieve them, and that it is actively monitoring progress and identifying emerging challenges that must be addressed as the policy goes forward. [This is] complex and includes issues such as how to coordinate worker education, dislocation, and educational pathways." In review of the data from the international exchanges, the project's external evaluator summarized these views writing that, "Participants viewed the German political and policy system as less volatile [as compared with the U.S and Australia] and perceive these differences as positively influencing renewable energy training and education." This finding is especially relevant given the expense associated with investment in new educational initiatives. If colleges and universities allocate money for training faculty and equipping facilities to teach 
renewable energy technology, they would like to have some assurance that the policies that are shaping the industry today will not undergo radical reversals in position before the current cohort of students even graduates.

Educational Finding \#2: Educational institutions should focus on the incorporation of renewable energy in core programs of study rather than the creation of new "specialty" degrees. Upon examination of the educational approaches taken in Australia and Germany, participants developed a consensus observation that students seeking to work in the renewable energy sector are most likely best served by educational programs that include instruction in traditional science, technology, and engineering fields. This sentiment was captured by one participant who commented that "we have heard many times from a variety of industries on this trip [to Germany] that it is not necessary to create specialized niche programs in this area [renewable energy]. Businesses and students are better served when the programs are based on a solid foundation of electromechanical courses. This strong, yet broad, core will allow students to transition, if needed, with the market." Another participant stated, "the Germans seem to have moved past the glitz of niche renewable energy training programs and have realized that the skills and knowledge needed to be successful in the renewable energy field are largely transferable from other industries such as electrical, industrial maintenance, and engineering." These findings have had implications for the participants who, upon their return to the U.S., have begun to examine how their renewable energy education programs might collaborate with traditional STEM fields through interdisciplinary efforts, and/or integrate with existing degree programs at their institution. In the years ahead, incorporation of emerging renewable energy technology with traditional degree programs may in fact offer opportunities for new innovations and institutional efficiencies, as both human and financial resources once dedicated to narrowly defined programs of study are leveraged and brought to bear on new renewable energy applications. Furthermore, by adopting this approach, educational institutions can somewhat hedge their renewable energy investments to insulate themselves against the unpredictable nature of U.S. energy policy.

Educational Finding \#3: Collaboration between education, industry and trade unions helps to shape renewable energy education. Participants were intrigued by the relationships by the Australian TAFE institutions and the ten Australian Industry Skills Councils. The Councils are privately registered not-for-profit companies run by independent industry led boards of directors, but whose funding is provided by the Australian Government through the Department of Education, Science and Training. The Councils give industry and trade unions a voice in Australia's education and training system. While this is not entirely unlike the voluntary advisory boards that are commonly found in U.S. college and university technical degree programs, the Australian model was notable in that public funding was provided to pay Council board members and staff for their efforts. In turn, the Councils were much more directly involved with identification of future industry workforce needs, establishing training requirements, and the compilation and preparation of industry skill reports. Guided by the Industry Skills Councils, the TAFE schools provide a wide diversity of course offerings, which range from a few hours for refresher courses, to short term (4 to 12 month) certificates, to more extensive ( 2 and 3 year) diploma programs. This flexibility also allows TAFE institutions to make possible a variety of student attendance patterns. The majority of TAFE students attend school part time, while combining work and study. Part-time attendance can include coursework during the day, in the evening, or through distance education. Academic work in some TAFE programs can be full time for several months of the year, combined with employment for the remainder. Alternatively, based on the input of local industry, some TAFE programs have been structured with several hours per week of academic instruction, delivered while the students are simultaneously working for a local employer. The participants in this study viewed the connection between Australian industry and the TAFE institutions as advantageous to students, allowing them to connect classroom theory to real-world applications, while providing clear pathways to the Australian workforce.

The German "dual-system" apprenticeship model of education is a unique system that presents an educational model quite different from the typical undergraduate student experience in the U.S. In the German dual-system, people can elect to learn one of roughly 350 apprenticeship occupations, and the skills and theory taught are defined by industry and regulated by national standards. In the dual-system, students are apprenticed to a company, where they are trained for three to five days a week. The company is responsible for providing the students with mentors, and ensuring that students get the standard quantity and quality of training required for each occupation. The other part of the dual-system involves approximately 60 days per year of vocational school (Berufschule), where students learn additional trade-specific theory, along with additional complimentary subject matter (e.g. mathematics, economics, information technology, and communication skills). The lessons typically are offered part-time (one or two days a 
week), although for some programs they may be grouped into concentrated of blocks of several weeks. The latter method is sometimes used for specialized trades (e.g. offshore wind energy) where students must travel to distant vocational schools or guild training sites that teach their chosen occupation.

Not unexpectedly, the German dual-system practice of strong industry involvement in the planning and development of educational programs was a focus of exploration for the American faculty. One participant noted that "It was almost a cultural understanding that - of course - industry is involved in education... it was difficult for the Germans to imagine a system like that of the U.S. where industry is only loosely involved with education. Even at the university level, [German] industry is closely tied to the education sector. In fact, most of their graduate degree holders work in industry, unlike the U.S. where a large number go to academia and work in institutions of higher education." Another participant observed that "Germany's national policy of 'education-industry-trade union' consensus when it comes to curriculum has been a great benefit in workforce development". Yet another wrote that "In the U.S. we tend to see industry involvement as having industry experts serve on advisory boards, teach as adjunct instructors, and provide potential employment for our graduates. Conversely, the German view of industry involvement is more about getting students out into industry settings where they can learn from the experts in the field." While it is probably unlikely that engineering education in the United States will ever adopt a systemic embrace of the German dual-system approach, these findings do have important implications for domestic engineering programs. The importance of industry engagement with education makes a strong argument for co-op and internship programs that are more commonly found in the U.S. Making these opportunities available to a larger number of students, and making them available earlier in undergraduate programs of study would help to confer many of the same benefits observed in the German dual-system to students not only in renewable energy, but rather in all of the various STEM fields.

\section{Impacts on Teaching Practice}

Participants reported a variety of ways that the experience had shaped their teaching practices (see Table 3 ). The two greatest impacts reported were that instructional faculty had developed new presentations or lecture materials for existing courses and had incorporated or increased the international perspective in their classes. Other significant impacts included the adoption of new instructional activities and innovations, and referring students to pursue international academic or career opportunities. For example, one participant commented "With the contacts that I made through the German and Australian Learning Exchanges I was capable of developing flipped classroom resources for a number of technical subjects". Another participant reported that since returning to the U.S., "I have used the model of alternating classroom and job experience with students being employees of the company". 
Table 3. Impact of the Learning Exchanges on participants teaching practices. Data sorted by weighted average to indicate degree of impact.

\begin{tabular}{|c|c|c|c|c|c|}
\hline \multicolumn{6}{|c|}{$\begin{array}{l}\text { How has participation with the international projects impacted your TEACHING PRACTICE as related to renewable } \\
\text { energy or sustainability? }\end{array}$} \\
\hline Answer Options & $\begin{array}{c}\text { Many } \\
(3)\end{array}$ & $\begin{array}{c}\text { Some } \\
(2)\end{array}$ & $\begin{array}{c}\text { A few } \\
(1)\end{array}$ & $\begin{array}{l}\text { None } \\
(0)\end{array}$ & Wtd. Ave. \\
\hline $\begin{array}{l}\text { I have developed new presentations or lecture } \\
\text { material for my existing courses }\end{array}$ & 5 & 2 & 2 & 1 & 2.10 \\
\hline $\begin{array}{l}\text { I have incorporated or increased the international } \\
\text { perspective in my courses }\end{array}$ & 2 & 7 & 1 & 0 & 2.10 \\
\hline $\begin{array}{l}\text { I have developed new written materials for my } \\
\text { existing courses }\end{array}$ & 3 & 3 & 2 & 1 & 1.89 \\
\hline I have adopted new instructional techniques & 1 & 4 & 4 & 0 & 1.67 \\
\hline $\begin{array}{l}\text { I have encouraged students to pursue international } \\
\text { academic or career opportunities }\end{array}$ & 1 & 3 & 6 & 0 & 1.50 \\
\hline $\begin{array}{l}\text { I have developed new units for my existing } \\
\text { courses }\end{array}$ & 1 & 2 & 5 & 1 & 1.33 \\
\hline $\begin{array}{l}\text { I have become involved with sponsoring student } \\
\text { international activities }\end{array}$ & 2 & 2 & 1 & 5 & 1.10 \\
\hline $\begin{array}{l}\text { I have connected my classroom to international } \\
\text { students or speakers }\end{array}$ & 0 & 0 & 5 & 5 & 0.50 \\
\hline $\begin{array}{l}\text { I have been assigned courses to which I was } \\
\text { previously not assigned }\end{array}$ & 0 & 1 & 0 & 9 & 0.20 \\
\hline I have developed entire new courses & 0 & 0 & 1 & 9 & 0.10 \\
\hline
\end{tabular}

\section{Impacts on Curriculum}

Nearly all of the participants reported that the International Experiences had shaped the curriculum of renewable energy programs offered at their institution in some way. $75 \%$ of respondents had adapted or expanded existing courses. $67 \%$ of the schools had changed how they were recruiting students, and $58 \%$ had changed how they were working with industry. $42 \%$ of the schools had adapted or expanded existing academic credentials, and $42 \%$ had changed how they were marketing renewable energy programs. One participant reported significant program changes at their institution to integrate renewable energy with traditional STEM fields that had directly resulted from his experience abroad, stating that "Photovoltaic concepts are being integrated into electrical courses, and solar thermal courses are being merged with hydronic courses". Another participant remarked, "One of the key takeaways from Australia was the connection between energy and water. At the time we visited, Australia was just recovering from a major decade long drought. One of the first things I did upon returning to the U.S. was to add a unit on the Water/Energy Nexus to my Survey of Renewable Energy course. This turned out to be even more relevant in the last couple of years as the Western U.S. has been severely crippled by drought that has drained reservoirs to historic lows."

The integration of renewable energy with other energy subjects and other STEM disciplines was another recurring theme in participant comments. Several participants commented on the examples of energy independent communities that were visited as part of the experience noting that every community or geographic location has different natural resources available for renewable energy production. Characterization of these assets is a key component of energy policy and planning, and should be foundational knowledge for students seeking to become future energy engineers and technicians. As one participant put it, "A key outcome of the international experience is that renewables are not a separate energy source or training, they are just a part of the overall energy mix - a mix often determined by policy makers". Similarly, another participant commented that one of the biggest lessons from the international experience was the importance of "Teaching all energy concepts together, rather than separating renewable energy from others". This was echoed by another participant who stated that "The visit to the geothermal site made me realize that the complexity of the operation requires many types of engineering. From this visit I 
realized that ALL of the renewable energy topics could be turned into project-based learning for students integrating physics, chemistry, mathematics, and engineering."

\section{Impacts on Professional Knowledge}

Participants reported considerable learning gains in terms of professional knowledge (See Table 4). The single greatest reported impact was the development of an understanding of renewable energy technology outside of the United States, followed closely by acquisition of new ideas about how industry and education could intersect. All of the participants reported expanded knowledge about renewable energy technology and energy efficiency, and all but one reported that they had developed collaborative professional relationships with fellow participants.

Table 4. Participant's professional knowledge self-reported learning gains. Data sorted by weighted average to indicate degree of impact.

\begin{tabular}{|c|c|c|c|c|c|}
\hline \multicolumn{6}{|c|}{$\begin{array}{l}\text { How has your participation with the international project(s) impacted your individual PROFESSIONAL } \\
\text { KNOWLEDGE DEVELOPMENT or COMMUNITY ENGAGEMENT as related to renewable energy or sustainability? }\end{array}$} \\
\hline Answer Options & $\begin{array}{l}\text { Very Much } \\
\text { (3) }\end{array}$ & $\begin{array}{l}\text { Some what } \\
\text { (2) }\end{array}$ & $\begin{array}{l}\text { A Little } \\
\text { (1) }\end{array}$ & $\begin{array}{l}\text { Did not occur } \\
\text { (0) }\end{array}$ & Wtd Ave. \\
\hline $\begin{array}{l}\text { Developed an understanding of renewable energy } \\
\text { policy outside the United States }\end{array}$ & 11 & 1 & 0 & 0 & 2.92 \\
\hline $\begin{array}{l}\text { Acquired new ideas about how industry and } \\
\text { education can intersect }\end{array}$ & 10 & 1 & 1 & 0 & 2.75 \\
\hline $\begin{array}{l}\text { Learned about technologies with which I was not } \\
\text { previously familiar }\end{array}$ & 8 & 3 & 1 & 0 & 2.58 \\
\hline Learned about unique or new technologies & 8 & 3 & 1 & 0 & 2.58 \\
\hline $\begin{array}{l}\text { Developed collaborative professional relationships } \\
\text { with fellow participants }\end{array}$ & 9 & 2 & 0 & 1 & 2.58 \\
\hline $\begin{array}{l}\text { Expanded my knowledge about renewable energy } \\
\text { technologies }\end{array}$ & 7 & 4 & 1 & 0 & 2.50 \\
\hline $\begin{array}{l}\text { Expanded my knowledge about building } \\
\text { efficiency }\end{array}$ & 5 & 5 & 2 & 0 & 2.25 \\
\hline $\begin{array}{l}\text { Acquired new techniques or approaches for } \\
\text { teaching my subject matter }\end{array}$ & 5 & 2 & 3 & 1 & 2.00 \\
\hline $\begin{array}{l}\text { Satisfied academic advancement or professional } \\
\text { development goals and/or expectations at my } \\
\text { institution }\end{array}$ & 5 & 2 & 3 & 1 & 2.00 \\
\hline $\begin{array}{l}\text { Developed collaborative professional relationships } \\
\text { with peers abroad }\end{array}$ & 1 & 2 & 4 & 4 & 1.00 \\
\hline $\begin{array}{l}\text { Influenced me to join related professional } \\
\text { organizations }\end{array}$ & 1 & 2 & 4 & 4 & 1.00 \\
\hline
\end{tabular}

The learning exchanges were very successful in developing faculty members' international perspective (see Table 5). $100 \%$ of the participants reported that they had developed an understanding of renewable energy technology and policy outside of the United States. All but one of the participants were "much more likely" to engage in discussions related to international advances in renewable energy (one was somewhat more likely). All of the participants reported that they were at least somewhat more attentive to international events and developments in renewable energy, with $83 \%$ being "much more attentive". As one participant commented, "It is easy to become self absorbed with your own specific field and lose sight of advancements that others are making. This experience has changed my perspective on other renewable energy fields and international industry". Another participant remarked that "Seeing efforts in developing renewable energy and efficiency in the countries we visited made me realize that that the U. S. could be doing much more in this arena". 
Table 5. Impact of the Learning Exchanges in developing faculty members' international perspective.

Data sorted by weighted average to indicate degree of impact.

\begin{tabular}{|c|c|c|c|c|c|}
\hline \multicolumn{6}{|c|}{ Do any of the following statements reflect changes you've experienced because of the international experience? } \\
\hline Answer Options & $\begin{array}{l}\text { Very much } \\
\text { (3) }\end{array}$ & $\begin{array}{c}\text { Some what } \\
(2)\end{array}$ & $\begin{array}{c}\text { A Little } \\
\text { (1) }\end{array}$ & $\begin{array}{l}\text { NA } \\
(0)\end{array}$ & Wtd. Ave. \\
\hline $\begin{array}{l}\text { I am more likely to engage in discussions related } \\
\text { to international advances in renewable energy }\end{array}$ & 11 & 1 & 0 & 0 & 2.91 \\
\hline $\begin{array}{l}\text { I am more attentive to international developments } \\
\text { in renewable energy }\end{array}$ & 10 & 2 & 0 & 0 & 2.83 \\
\hline $\begin{array}{l}\text { I am more likely to engage in conversations about } \\
\text { international energy policy }\end{array}$ & 10 & 1 & 0 & 1 & 2.67 \\
\hline $\begin{array}{l}\text { I am likely to be active as an energy policy } \\
\text { advocate }\end{array}$ & 6 & 4 & 0 & 2 & 2.17 \\
\hline
\end{tabular}

\section{Impact on Community Engagement and Dissemination}

In terms of community engagement and dissemination efforts, participants engaged in a wide variety of activities to share their experiences with others (see Table 6). 100\% of the participants reported that they had discussed their experiences with peers and with administrators at their college campuses, and all but three had delivered lectures or presentations on the subject at their college. Several participants had also delivered talks to other energy professionals, or as part of a professional conference or symposium.

Table 6. Modes of post-trip knowledge dissemination by learning exchange participants. Data sorted by weighted average to indicate frequency of occurrence.

\begin{tabular}{|c|c|c|c|c|c|c|}
\hline \multicolumn{7}{|c|}{ How have you disseminated the knowledge you gained through this experience? } \\
\hline Answer Options & $\begin{array}{c}>\text { or }=5 \\
\text { times } \\
(5)\end{array}$ & $\begin{array}{c}3-4 \\
\text { times } \\
(3)\end{array}$ & $\begin{array}{c}\text { twice } \\
(2)\end{array}$ & $\begin{array}{l}\text { once } \\
\text { (1) }\end{array}$ & $\begin{array}{r}\text { NA } \\
(\mathbf{0})\end{array}$ & Wtd. Ave. \\
\hline Discussed this with peers at my institution & 9 & 3 & 0 & 0 & 0 & 4.5 \\
\hline $\begin{array}{l}\text { Discussed what I learned with my school } \\
\text { administration }\end{array}$ & 6 & 2 & 3 & 1 & 0 & 3.58 \\
\hline $\begin{array}{l}\text { Delivered presentations/lectures as part of a } \\
\text { conference or symposium }\end{array}$ & 0 & 5 & 1 & 0 & 5 & 1.55 \\
\hline $\begin{array}{l}\text { Delivered presentations/lectures to other energy } \\
\text { professionals }\end{array}$ & 2 & 0 & 2 & 4 & 3 & 1.64 \\
\hline $\begin{array}{l}\text { Delivered presentations/lectures to faculty at my } \\
\text { institution }\end{array}$ & 1 & 1 & 3 & 3 & 3 & 1.54 \\
\hline $\begin{array}{l}\text { Delivered presentations/lectures to my school } \\
\text { administration }\end{array}$ & 1 & 1 & 2 & 2 & 5 & 1.28 \\
\hline $\begin{array}{l}\text { Delivered presentations/lectures to the general } \\
\text { public }\end{array}$ & 0 & 1 & 2 & 0 & 8 & 0.63 \\
\hline Written articles & 0 & 1 & 0 & 2 & 8 & 0.45 \\
\hline $\begin{array}{l}\text { Presented before government or regulatory } \\
\text { agencies }\end{array}$ & 0 & 0 & 0 & 3 & 8 & 0.27 \\
\hline
\end{tabular}

Participants also shared their experience with a wide variety of audiences with an interest in renewable energy (see Table 7). Dissemination activities were estimated to have reached a total of 925 students and 330 faculty members in the 18 months following the conclusion of the learning exchange projects, making these the largest dissemination audiences. Participants also estimated that they had shared these experiences with over 150 other energy professionals, business and industry partners, and general community members. 
Table 7. Participant dissemination estimates of the number of individuals with whom they had shared their international experiences. Data sorted by frequency.

\begin{tabular}{|c|c|c|}
\hline \multicolumn{3}{|c|}{$\begin{array}{l}\text { Please estimate the number of people from the following groups with whom you have shared information, insights, or } \\
\text { details about your international experience }\end{array}$} \\
\hline Answer Options & Total & Average Number \\
\hline Students & 925 & 84 \\
\hline Educators & 330 & 30 \\
\hline Energy Professionals & 167 & 15 \\
\hline General Community members & 157 & 14 \\
\hline Business and Industry Contacts & 150 & 14 \\
\hline School Administrators & 67 & 6 \\
\hline Govt Agency or Regulatory Officials & 50 & 5 \\
\hline Elected Officials & 21 & 2 \\
\hline
\end{tabular}

\section{Impact on Teaching Perspectives and Professional Growth}

Given the magnitude (and expense) of this international project, we were also motivated to assess impacts that may have transformed participants' world views or significantly altered their careers. For this reason, we asked participants to identify the most significant lasting impact that resulted from the learning exchanges. Many participants cited the importance of visiting industry sites and observing their relationship with educational systems abroad. One participant commented, "I find that since this project, I have developed a new awareness of the importance of training on the technical level and how community colleges have a critical role in workforce development". Another participant noted "After seeing the commitment of industry in both Australia and Germany in the education of their workers, I have been more driven to have student internships paid, and to encourage companies to share in the continued education of their workers." This was echoed by yet another who said, "Hearing about the German educational system and their apprenticeship structure gives me the confidence to suggest changes to the Joint Training Apprenticeship Committee in my state". These statements show how participants have attempted to translate their observations of best practices abroad into changes in practice for the renewable energy sector in the United States. Based on our experience, we believe that a variety of other STEM disciplines could benefit from a similar examination of the relationships between industry and education sectors in other countries.

Working, traveling, and interacting with a cohort of like minded educators/peers was also indicated by many as having a lasting impact on teaching practice. As one participant said, "CREATE has established an amazing community of renewable energy professionals. Interacting with my peers, and sharing common experiences has helped me to develop a professional network that spans the United States. This is very helpful, since renewable energy is still a relatively young field. There are not that many renewable energy educators in my state, and most do not have very many years of classroom experience. It is invaluable to be part of this network of experts, and I have learned immeasurably as a result. There is no question that my association with CREATE has advanced my expertise and my career." This comment reflects the importance of the creation of a learning community - a key ingredient to the success of any international program that engages a group of individuals who will be travelling and cooperating with one another closely over an extended period of time. Considering these results along with the dissemination activities reported by participants, it is clear that even though these learning exchanges were shortterm experiences, they have succeeded in establishing long-term relationships that have persisted beyond the duration of the initial activity. This has resulted in partnerships and collaborations that have now spanned several years, and in all likelihood will continue well into the future.

\section{Perceived Value of Project Learning Activities}

As described above, the two learning exchanges clearly yielded significant impacts for the participants in terms of their teaching practice, curriculum development, professional knowledge and academic community involvement. These results clearly support the internationalization of curriculum and instruction in other engineering fields. In an effort to identify the components deemed most critical to creating and delivering high quality international professional development experiences for future organizers of such projects, participants were asked to report on the 
value of the various learning activities that were included as a means to support, encourage and capture participant knowledge-building.

One of the key activities, the "pre-visit site reports" were noted as valuable both before and during travel. The reports, which required participants to research a site to be visited, and then present this information to their peers online (pre-travel) and while en route (during travel), were one of the most highly rated activities. All but two of the participants reported that preparing the pre-visit site reports was "very useful" with the remaining participants ranking this as "somewhat useful". Likewise, during travel, the pre-visit site report presentations delivered by their peers were viewed as "very valuable" by two-thirds of the participants, and "somewhat valuable" by the remainder. This highlights the importance of having structured tasks which engage participants with the sites and personnel that they will be visiting abroad - both before and during the trip - in order to provide scaffolding that can maximize the learning gains beyond that which otherwise might occur from just a simple visit lasting only a day or less.

When considering post-trip activities, all of the participants indicated that working with a colleague to prepare a summary "sector report" that examined their renewable energy technology sector and compared U.S. practices with those abroad, helped to solidify knowledge gained as a result of the learning experience. Similar ratings were given for "individual inquiry reports" that required participants to investigate a framing question of their choice over the course of the experience. Seven respondents ranked these activities as "very valuable" with the other five ranking them as "somewhat valuable".

Although only seven of the survey respondents delivered conference presentations, participated in panels, or authored papers as representatives of CREATE, all seven ranked these activities as "very valuable" post-travel learning activities. This emphasizes the importance of providing opportunities for dissemination to others who might participate in similar international experiences for faculty professional development. Organizers of future international opportunities would be advised to plan for these types of dissemination activities, and to build participant support funds into project budgets to encourage these outcomes.

In addition to rating the learning activities, participants were also asked to reflect on additional information they would have appreciated prior to travel. The single most desired category was for additional information about the geography and environmental conditions that influenced the use of renewable energy in the countries visited (50\% of respondents). This was followed closely by a desire for more information about the educational systems and industry sectors in the countries visited. Given the wide variety of educational practices worldwide, and differing models for the interaction between education and industry to produce a skilled workforce, it would seem that this is likely to be an area of interest for faculty involved in any other type of learning exchange. This conclusion is reinforced by the fact that every one of the Germany participants rated the one-day seminar at the Boell Foundation prior to travel as a valuable experience. We attribute this finding to the rich overview that the Boell Foundation provided on the state of the renewable energy industry in Germany, and their detailed explanation of the unique German educational and apprenticeship system, which can be somewhat complex to grasp for those who are only familiar with the academic model found in the United States.

\section{CONCLUSIONS}

\section{Internationalizing STEM Education}

While this study focused on the field of renewable energy, the findings are relevant for all of the STEM disciplines. For example, one could imagine an international learning exchange of automotive engineers travelling to Japan to study the Toyota Production System, or a group of transportation engineers traveling to Europe to study high-speed rail. There are countless other possible examples, but the core concept is that the engineering profession is now characterized by a global workforce. This behooves engineering educators to pursue international professional development opportunities, so that they are able to promote global literacy with their students. It also provides an impetus for other educational organizations and/or institutions of higher education to create programs that provide faculty with international professional development opportunities. The authors recognize the challenge of creating such programs from scratch, and thus we offer here some advice that should help others learn from our experience. 


\section{Addressing the Skeptics}

For some individuals, financial support of international travel may be perceived as an improvident use of funds. This is particularly true for those that have never been engaged in an international professional development, and do not have knowledge of the merits of such programs. It also may be true for individuals that advocate for limited government spending who are motivated to unearth and expose examples of publicly funded programs that they find questionable. Organizers of international professional development programs must be prepared to encounter this sort of opposition, and should be prepared to answer questions and defend the merits of their programs. Here we offer responses to two of the most common criticisms that we have experienced, to help others address and refute these arguments.

\section{Frequent Criticism 1: "Faculty can travel on their own."}

Arguments such as the one above fail to recognize the difference between personal travel for leisure versus organized professional development programs. A faculty member travelling as an individual is not easily able to meet with groups of academics from abroad, to visit industry sites, or to interact with policy makers, employers, or other stakeholders. Orchestrating these types of activities requires a group leader who is well networked to make contacts, organize, and plan months ahead of time; the development and inclusion of a coordinated participant learning and outcomes plan further deepens the rigor of the professional development of the participants. This is completely unlike personal travel where a person purchases a plane ticket, reviews a copy of a travel guide from the library, and then consults the visitor information kiosk upon arrival abroad to book a bus tour of the top ten local site-seeing attractions.

Furthermore, when travelling as a faculty group, there is a critical mass of experts with similar backgrounds that facilitate networking. This allows people with similar teaching and research interests to share ideas and develop new innovations. That also means that the success of any international professional development program will depend in part on the ability of the organizers to recruit, screen and select a strong pool of participants for the experience. By carefully selecting the group, organizers can assemble a panel of educators with a range of disciplinary expertise, which makes it more valuable for groups of overseas hosts to spend time with the visiting delegation. Furthermore, structured learning activities that engage participants in dialogue with one another allow for reflection, collaboration, and distillation of key points to reach meaningful conclusions for the international experience.

\section{Frequent Criticism 2: "Isn't this just a junket?"}

According to the Cambridge Dictionary of the English Language (2016), the definition of the term junket is given as, "a journey or visit made for pleasure by an official that is paid for by someone else or with public money" (bold text indicates authors emphasis). The key distinction here is that international professional development programs are not made for pleasure. Rather the purpose of such programs is to educate the participants and increase their global expertise, so that they can share this knowledge with others upon their return and make our country more competitive in the international marketplace. A simple recommendation to help draw this contrast is for program organizers to avoid using terms like " travel", "trips", and "tours", when describing their programs, since these often have leisurely connotations. Instead it is preferable to use phrases such as international study, international professional development, or international learning exchange to describe such programs.

Of course, the most important strategy for program organizers and funding agencies to refute the "junket" argument is to ensure that international professional development programs are well planned, tightly structured, rigorous, and well documented. When conceiving the program, organizers should think hard about the changes, outcomes, and impacts that they seek to achieve. They then must convey that message to participants, and structure the travel experience to help produce those results. Competitive application and selection processes ensure that only highly qualified and motivated individuals are chosen to participate, enhancing the likelihood of success. Assessment should be built into the experience, both before and during travel, as well as immediately after and 1-3 years later to measure both immediate outcomes and longer lasting project impacts. Finally, it is of great importance to report and disseminate the knowledge gained so that others beyond the small network of participants can learn and benefit from the project findings. 
Recommended practices for international professional development programs. Over the past few years while sharing the results of this project with others, we have been asked on several occasions if we could summarize the key elements necessary to create a successful study abroad program. While we do not claim to be the ultimate authority on this subject, we provide a short list here that distills the main components based on our experience.

- Design and implement a competitive nomination, application and participant selection process to assemble a strong community of practice that embodies professional diversity and excellence as well as ensures a personal commitment by those selected to participate.

- Use pre-trip study, webinars, and assignments to establish baseline knowledge, to foster relationships between participants, and to build the context for the international experience. This front-end work also helps ensure the best use of valuable time abroad.

- Work with partners/coordinators overseas to establish meaningful exchanges with international counterparts. Program coordinators should cultivate connections to academia, industry, and governmental agencies to build a robust and multifaceted program itinerary.

- If traveling to a region that speaks a language other than English, retaining the services of consultant translators with both foreign language and technical expertise will facilitate site visits that require command of both for effective communication

- Use post-trip assignments for participants to debrief on their experience and create a sense of closure. Structured activities help participants to apply what they learned to their own instructional practices.

- Plan and budget for dissemination opportunities for participants. Conference presentations and panel discussions provide forums to cement lessons learned and share experiences with others, thereby magnifying the impact of the project.

- Plan to measure both immediate outcomes and longer-term impacts to assess the success of the project. Since the latter results often take 1-2 years to manifest themselves, it is important the project organizers plan and budget accordingly to capture such impacts.

\section{SUMMARY}

The CREATE Learning Exchanges serve as a model program for providing STEM faculty with rich international professional development experience. The findings in this manuscript highlight the key components to building a successful international professional development program, and illustrate the type of impacts that can result from these activities. These lessons learned will be meaningful to any other institutions or organizations planning similar international activities in a variety of engineering disciplines.

\section{ACKNOWLEDGEMENTS}

This material is based upon work supported by the National Science Foundation under grants \#1002653 and \#1600934. The international faculty professional development programs were funded by supplemental awards $\# 1239631$ and \#1345306. The international experiences described in this paper were facilitated by the invaluable organizational support provided by CREATE Project Manager Gabrielle Temple. Assistance with the creation of the participant survey and assessment of the project's impact was provided by CREATE Evaluator Dr. Jean Sando. Thanks also to CREATE learning exchange participants Roger Ebbage, John Galisky, Andrew McMahan, Jim Pytel, and Troy Wanek who contributed to several panel discussions and presentations that led to the development of this manuscript.

\section{AUTHOR BIOGRAPHIES}

Dr. Kenneth Walz completed his Ph.D. at the University of Wisconsin in Environmental Chemistry and Technology, while conducting electrochemical research with Argonne National Laboratory. His studies also included research with the University of Rochester Center for Photo-Induced Charge Transfer. Since 2003, Dr. Walz has taught chemistry, engineering, and renewable energy at Madison Area Technical College, and he is also an adjunct professor with the department of Civil and Environmental Engineering at the University of Wisconsin. Dr. Walz is an alumnus of the Department of Energy National Renewable Energy Laboratory Academies Creating Teacher Scientists Program. Dr. Walz has been recognized as Professor of the Year by the Carnegie Foundation and 
the Council for Advancement and Support of Education, and as the Energy Educator of the Year by the Wisconsin Association for Environmental Education K-12 Energy Education Program.

Mary Slowinski is an educator/consultant specializing in collaborative learning research and design. She received her M.Ed. and Ph.D. in Learning Science from the University of Washington with a focus on communities of practice for educators. She has worked extensively with the National Science Foundation's Advanced Technological Education program in a variety of consulting capacities including serving as learning coordinator for two international faculty learning projects, collaborating as an innovation coach to assist with scaling up innovations in technical education, developing curricular and learning materials based on learning science, and facilitating groups in a variety of settings. Slowinski is tenured faculty at Bellevue College where she chairs the Digital Media Arts program.

Kathleen Alfano has a Ph.D. from UCLA in Higher Education with a cognate in administration and evaluation. Her B.S. is in chemistry, and she worked as an analytical chemist in industry before returning for her M.S. and pursuing a career in education. She served as founder and Director of the California Consortium for Engineering Advances in Technological Education (CREATE) from 1996 to 2016 with funding from the National Science Foundation. She is a tenured faculty member at College of the Canyons, where she also served as Dean of Professional Programs and Academic Computing from 1996-2000. Dr. Alfano served as a Program Director at the National Science Foundation and co-lead of the Advanced Technological Education program in 2007-2008. Dr Alfano was also the sole community college representative on the 2013 National Academy of Sciences Committee on Workforce Trends in the U.S. Energy and Mining Industries.

\section{REFERENCES}

ABC (2014). Australian Broadcast Company. Carbon Tax: A timeline of its tortuous history in Australia. July 17, 2014.

Agora (2015). Understanding the Energiewende. FAQ on the ongoing transition of the German power system. www.agoraenergiewende.de

Cambridge Dictionary of the English Language (2016). Accessed online at: http://dictionary.cambridge.org/dictionary/english/junket

Daniel, S.; Xie, F.; and Kedia, B. (2014). U.S. Business Needs for Employees with International Expertise. Center for International Business Education and Research. University of Hawai'i at Manoa Accessed online at: http://globalsupport.tamu.edu/Footer-Links/Resources-Center/Global-Publication/2014-US-Business-Needs-forEmployees-with-Internat.aspx

Preston, K. (2012). IES Abraod Recent Graduates Survey: The Impact of Studying Abroad on Recent College Graduates' Careers 2006-2011 Graduates. Accessed online at: http://www.iesabroad.org/system/files/recentgraduatessurvey.pdf

Lincoln Commission (2005). Global Competence and National Needs: One Million Americans Studying Abroad. Commission on the Abraham Lincoln Study Abroad Fellowship Program. One Dupont Circle, NW Suite 250, Washington, DC 20036.

NAE. (2005). Educating the Engineer of 2020: Adapting Engineering Education to the New Century. National Academy of Engineering. ISBN 0-309-55006-8. National Academies Press, 500 Fifth Street, N.W., Lockbox 285, Washington, DC 20055.

NAFSA. (2015). Trends in US Study Abroad. NAFSA: Association of International Educators 1307 New York Avenue N.W., 8th Floor, Washington, D.C. 20005. Accessed online at: http://www.nafsa.org/Policy_and_Advocacy/Policy_Resources/Policy_Trends_and_Data/Trends_in_U_S_Study_Abr $\mathrm{oad} /$

Slowinski, M. and Alfano, K. (2015). Renewable Energy Technician Education: Lesson from the German Engergiewende. ASEE Annual Conference and Exposition Proceedings, Energy Conversion and Conservation Division. Seattle, WA

Slowinski, M, Walz, K and Alfano, K. (2016). Renewable Energy Technician Education: The Impact of International Faculty Collaboration. ASEE Annual Conference and Exposition Proceedings, Energy Conversion and Conservation Division. New Orleans, LA. 


\section{NOTES}

